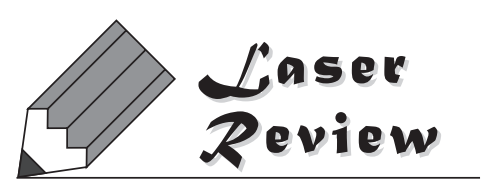

\title{
高出カレーザー伝送用光ファイバの信頼性技術
}

\author{
兵頭 隆史, 石田智彦, 山川 禎貴, 谷口 浩一 \\ 三菱電線工業 (株)（７６60-0856 兵庫県尼崎市東向島西之町8番地）
}

\section{Reliability Technology of Laser Delivery Fiber for High Power Laser}

\author{
Takafumi HYODO, Tomohiko ISHIDA, Yoshiki YAMAKAWA, and Hirokazu TANIGUCHI \\ Mitsubishi Cable Industries, LTD., 8 Nishino-cho, Higashimukojima, Amagasaki, Hyogo 660-0856
}

(Received March 26, 2012)

\begin{abstract}
Laser technologies are extensively used in the various fields such as material processings, medical treatments, and measurements. Especially, the developments of the high power laser with excellent beam quality such as fiber lasers have advanced in the laser machining fields, which are for the production line of the automotive body and the lithium ion battery. In the fields, the laser power transmission technologies by using laser delivery fibers are indispensable and the higher reliability is increasingly required. In this report, we introduce the overview about the preparation methods, which are a laser polishing and an end-cap structure, for the optical fiber end face and the connector technology that is a cladding mode stripper. These technologies can be expected to support the reliability of the laser delivery fibers.
\end{abstract}

Key Words: Laser delivery fiber, Laser induced damage threshold, Laser polish, Cladding mode

\section{1. 緒 言}

レーザー技術は急速な進展を遂げ, 加工, 医療, 計測 をはじめ様々な分野で盛んに利用されている。特にレー ザー加工分野では，ファイバレーザーを中心とした，出 カがキロワットを越える高ビーム品質レーザーの開発が 進み, 自動車ボディやリチウムイオン電池の製造ライン への導入が進んでいる. また近年, 高密度にスタックさ れた高出力半導体レーザーを用いたダイレクトダイオー ドレーザー (DDL) 加工が盛んに行われており，ファイ バレーザーを凌ぐ高い光変換効率による金属表面加工も 進んでいる。一方, 実際のレーザー加工の現場では, 多 くの場合, 加工用レーザー発振器と加工用ヘッドの空間 的な配置の自由度が要求され，光ファイバを用いたレー ザーエネルギー伝送は欠かせない技術となっている。し かし, 近年の加工用レーザー発振器の高出力化に伴い, 光ファイバ端面のレーザー損傷しきい值の向上など，従 来よりも更に高い耐久性がレーザー伝送用光ファイバに 求められている。 そこで本稿ではレーザー伝送用光ファ イバに関して，その信頼性を支える光ファイバ端面加工 技術，及びコネクタ技術の概要について紹介する。

\section{2. レーザー伝送用ファイバの損傷事例}

高出力レーザーエネルギーを伝送するレーザー伝送用
光ファイバでは，コネク夕部分の損傷が圧倒的に多く, その損傷部位のほとんどは, 光ファイバ端面と光ファイ バ被覆部である。すなわちレーザー伝送用光ファイバの 信頼性の向上は, 光ファイバ端面と光ファイバ被覆部の 耐久性の向上に支えられていると言える(Fig. 1).

Fig. 2は光ファイバ端面の典型的な損傷の様子を示し ている。損傷初期 (Fig. 2 (a))では，中心部分に薄く影 が存在しており,この部分が損傷の核となる。 その後, 中心部分が溶融し(Fig. 2(b)), さらに損傷が進むと, 光ファイバ端面が高温となり, 最終的にはコネクタ部材 を含む全てが焼損(炭化を伴う焼け)に至る (Fig. 2 (c)). 多くの場合, 損傷の核となるのは, 外部 から飛来して付着した異物であり，レーザー出力が大き くなるほど，光ファイバ端面周辺のクリーン度を高く保

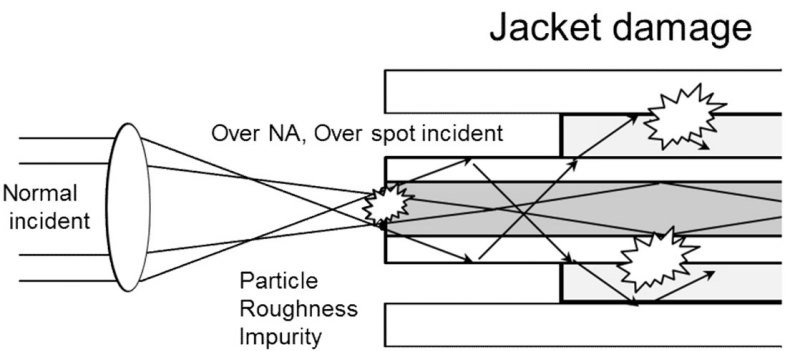

End face damage

Fig. 1 Damages in the connector for laser delivery fibers. 


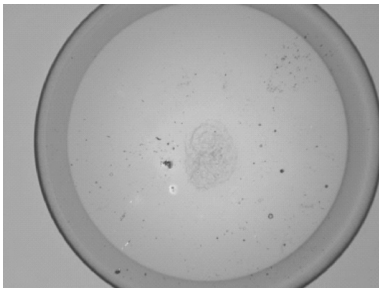

(a)

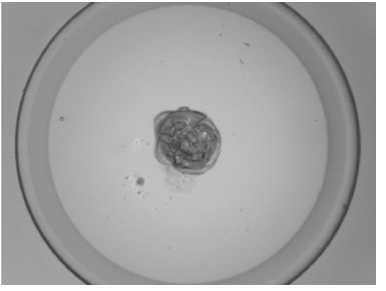

(b)

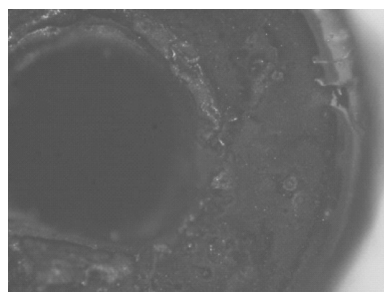

(c)

Fig. 2 Damage processes in the optical fiber end face.

(a) Initial damage. (b) Partial melting. (c) Whole melting.

つことが重要となる.

Fig. 3はコネクタ内部の光ファイバ被覆部の典型的な 焼損の様子を示している. 被覆部の焼損は, 光ファイバ 端面に近い被覆端部から起こり，この原因の多くは，コ アに正常に入射されなかったレーザー光が被覆部に吸収 されて，発熱することに起因している。

また非常に少ない事例ではあるが，レーザー伝送用光 ファイバでも通信用光ファイバと同様にファイバヒュー

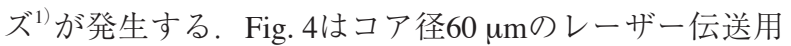
光ファイバで生じたファイバヒューズの様子を示してい る. Fig. 4 (a) は出射端近傍で生じたコア内の空隙, Fig. 4 (b) は同ファイバの導中でのコア内の空隙を示し ている. 空隙の形状は砲弾型をしており, 砲弾型の先端 (曲率) 部が出射側, 砲弾型のフラット部がレーザー光源 側を向いており，通信用光ファイバで確認されている空 隙の形状とほぼ同等である2)。なお同ファイバでは，外 見上は端面のみの損傷であったが，ファイバヒューズが 生じた全長に渡って, 光ファイバの機械強度が著しく劣 化しており，コア中を高温で伝搬するファイバヒューズ の影響が大きいことが確認された. ファイバヒューズ

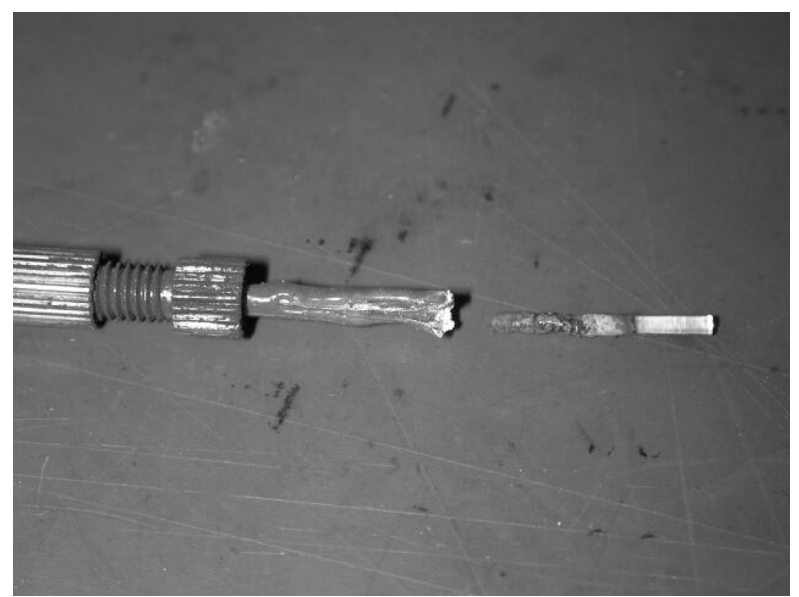

Fig. 3 Damage of fiber jacket in the connector.

第 40 巻第 6 号 高出力レーザー伝送用光ファイバの信頼性技術

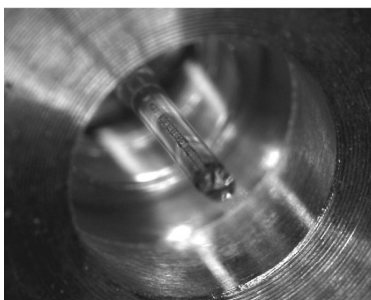

(a)

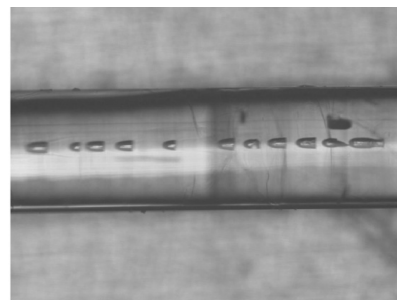

(b)
Fig. 4 Micrograph of the void generated by fiber fuse.

(a) Fiber fuse damage in the near output end face.

(b) Void in the fiber core.

は，レーザーの出射端面に異物が付着し，端面温度が約 $1000^{\circ} \mathrm{C}$ に達すると生じるとの報告があり ${ }^{3)}$ ， レーザー伝 送用光ファイバでも出射端面付近のクリーン度を高く保 つことが重要である。

\section{3. レーザー伝送用光ファイバの信頼性向上技術}

\section{1 光ファイバ端面の耐久性向上技術}

3.1 .1 表面粗さと残存不純物の影響

光ファイバ端面のレーザー損傷しきい值は，前述の異 物の付着以外に，端面の表面粗さや残留する研磨剂等の 不純物に影響されることが知られている ${ }^{4)}$ ，端面に研磨 加工などによる微視的な欠け，傷が存在する場合，これ らが入射されるレーザーの電界強度を増強させ，主にパ ルス発振レーザーに対する耐性を低下させる要因になる と考えられる。また研磨剤などの不純物が端面に残留す ると，これらの不純物がレーザー光を吸収し，局所的に 高温になることでプラズマが発生し，容易に端面を損傷 すると考えられる゙．

一般的に行われている機械式研磨で形成した光ファイ バ端面を原子間力顕微鏡 (Atomic Force Microscope: AFM) により観察した。使用した光ファイバは,コア径 $600 \mu \mathrm{m}$ のステップインデックス (Step Index: SI) ファイバ である.Fig. 5 (a) は機械式研磨を行った光ファイバ端 面のAFM像（長さ10 $\mu \mathrm{m} \times$ 幅10 $\mu \mathrm{m}$ 領域）を示している. 観察の結果，表面には無数の線状の研磨傷 (スクラッチ 傷)が残っており，表面粗さ ( rms值) は $0.48 \mathrm{~nm}$ 程度と なっていることが判った，次に機械式研磨を行った光

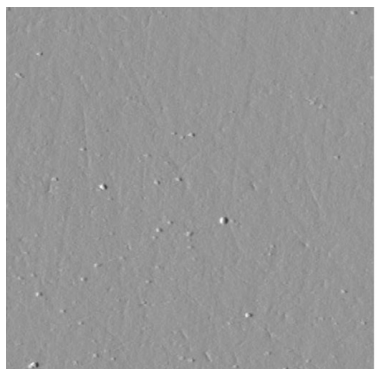

(a)

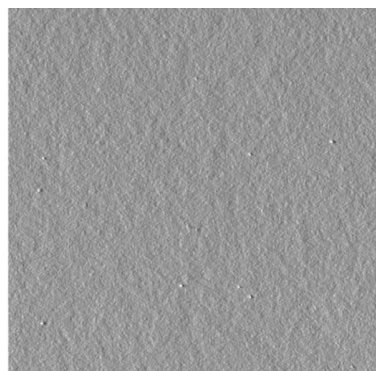

(b)
Fig. 5 AFM images of the end face of the optical fiber polished by conventional mechanical polishing and laser polishing. Scanning area of $10 \times 10 \mu \mathrm{m}^{2}$. (a) Mechanical polishing. (b) Laser polishing. 
ファイバ端面について, 二次イオン質量分析 (Secondary Ion Mass Spectrometry: SIMS)を用いて，表面近傍に残留 する不純物を分析した. Fig. 6は検出された不純物の二 次イオン強度の染さ分布を示している。これより表面か ら深さ100 nm程度まで, 研磨剤に含まれるセリウム $(\mathrm{Ce})$, ランタン $(\mathrm{La})$ 等の不純物元素が残留しているこ とが判る、Ce等の元素に関しては, 可視域や紫外域の レーザーに対する耐性を劣化させるとの報告 ${ }^{6}$ があり， 今後進展が期待される短波長レーザー加工へのレーザー 伝送用光ファイバの適用の際には, 光ファイバ端面での 不純物元素の管理が重要な課題になると考えられる。 れらのことから機械式研磨で形成した光ファイバ端面の レーザー損傷しきい值を向上させるためには，研磨傷と 表面粗さの低減, そして残留不純物の管理が必要と考え られる。

\section{1 .2 プラズマエッチング技術}

大気中アーク放電のプラズマの温度は, 一般に数 $1000{ }^{\circ} \mathrm{C}$ に達することが知られており，プラズマ中に光 ファイバ端面を曝すことで, 石英材料の最表面を蒸散 し, 機械式研磨で浸入した不純物を除去し, さらに光学 的に平滑な端面を形成できる可能性がある。 そこで機械 式研磨を行なった後の光ファイバ端面のプラズマエッチ ング処理を行った。 使用した光ファイバは, コア径 $600 \mu \mathrm{m}$ のIファイバである.

プラズマエッチング後の光ファイバ端面をAFMによ り観察を行ったところ, 機械式研磨で生じた線状の研磨 傷 (スクラッチ傷)が大幅に減少し, 表面粗さ (rms值)は $0.19 \mathrm{~nm}$ 程度まで改善されることが判った。 次にプラズ マエッチング後の光ファイバ端面について, SIMSによ り表面近傍の不純物分析を行った. Fig. 6にはプラズマ エッチング後のCeの二次イオン強度の深さ分布を示し ている。これよりプラズマエッチング処理を行うこと で，端面近傍に存在していたセリウムが大幅に削減でき ることが判る。しかしながら二次イオン強度からはCe が完全に除去されているかは不明であり，除去される一 方, 一部がプラズマエッチング処理中の熱で再拡散して いる可能性も考えられる.

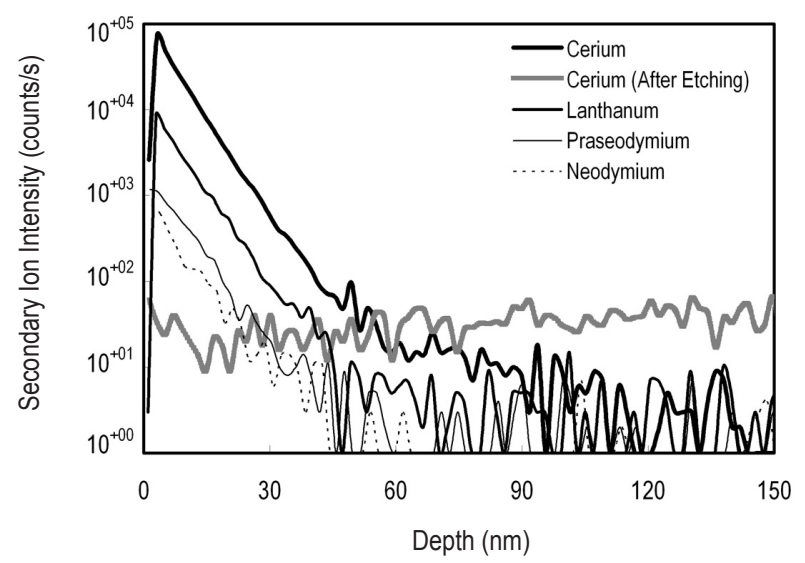

Fig. 6 Impurity depth profiles of the end face of the optical fiber polished by conventional mechanical polishing and plasma assisted etching.

\subsection{3 レーザーポリッシュ技術}

光ファイバを構成する石英ガラスは, 赤外波長 $9.1 \mu \mathrm{m}$ に二酸化ケイ素 $\left(\mathrm{SiO}_{2}\right)$ の分子振動による強い吸収ピーク を持っており ${ }^{7)}$, その吸収の裾にある炭酸ガス $\left(\mathrm{CO}_{2}\right)$ レーザーの発振波長10.6 $\mu \mathrm{m}$ に対しても，強い光吸収が

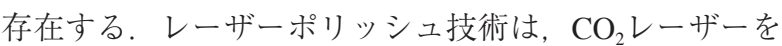
光ファイバ端面に照射することで, 石英ガラスの最表面 を選択的に加熱蒸散させ，光学的に平滑な表面を形成す る技術である ${ }^{8)}$. 従来の機械式研磨と異なり，研磨紙や 研磨剤を全く使用しないため，不純物の浸入は無く，非 常にクリーン度の高い表面が得られる。

実験では $\mathrm{CO}_{2}$ レーザー発振器からのレーザー光をビー ムエキスパンダ, フォーカシングレンズ等から構成され る光学系を介して, 光ファイバ端面に集光し, レーザー ポリッシュを行った。

使用した光ファイバは，コア径600 $\mu \mathrm{mSI}$ ファイバであ る. Fig. 5 (b) はレーザーポリッシュ行った後の光ファ イバ端面のAFM像(長さ $10 \mu \mathrm{m} \times$ 幅 $10 \mu \mathrm{m}$ 領域)を示して いる。 AFM観察の結果, 表面粗さ (rms值)は0.20 nmであ り，プラズマエッチング処理とほぼ同等の表面粗さが得 られており，機械式研磨後に多数観られた研磨傷(スク ラッチ傷) は全く無く, 非常に平滑な表面が得られてい ることが判った.

\subsection{4 レーザー損傷しきい值の評価}

レーザー伝送用光ファイバでは，光ファイバ端面での フレネル反射損失を減らすため, 無反射 (Anti-Reflection: AR) コーティングを施すことが多く，特にレーザーマー キングやトリミングなどのパルスレーザー加工用途では ARコーティングに対して高い耐久性が要求される。一 般にARコーティングのレーザー損傷しきい值は, 下地 となる基板の表面状態に影響されることが知られてい る9). 表面状態が良好でない場合, 膜の密着性低下や微 視的な段差による電界強度の増強により，レーザー損傷 しきい值が低下する。前述のプラズマエッチング処理, レーザーポリッシュ技術の効果を検証するため, これら の処理を施したSIファイバ端面にARコーティングを行 い，Qスイッチパルスレーザーに対するレーザー損傷し きい值の評価を行った，光ファイバ端面へのARコー ティングは, 酸素イオンアシストを採用した電子ビーム 蒸着法により行っている

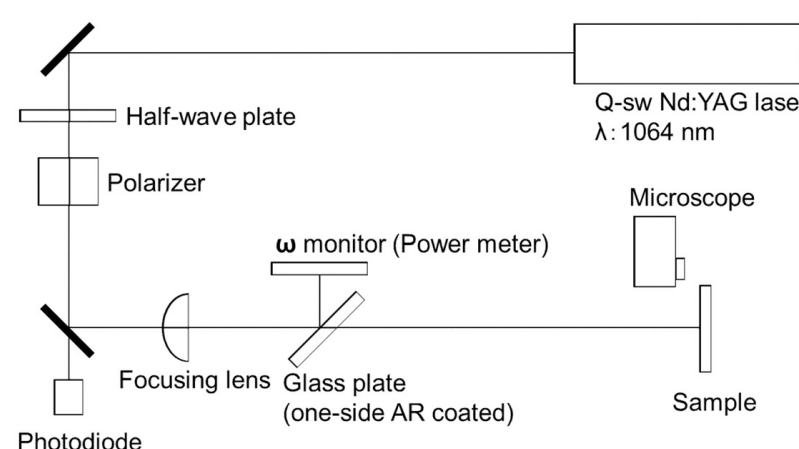

Fig. 7 Experimental setup of laser damage test. 
Fig.7はレーザー損傷しきい值の測定系の構成を示し ている。レーザー発振器には $Q$ スイッチNd:YAGレー ザー（波長1064 nm，パルス幅10 ns)を用いた。レーザー 出力は, 偏光子と $\lambda / 2$ 板からなるエネルギー調整器で照 射エネルギー強度を調整し，焦点距離 $F=600 \mathrm{~mm}$ の フォーカシングレンズにより，光ファイバ端面に直径約 $300 \mu \mathrm{m}$ のポットサイズで集光している。 またレー ザー損傷の有無は，損傷時にサンプル表面で発生するプ ラズマ発光，パワーメータによる出力変動，顕微鏡よる 損傷面の観察により決定した。 なお試験方法は, 同一箇 所にレーザー光を照射し，1パルス毎に照射エネルギー を少しずつ増加させて, 損傷の有無を確認する方法 (N-on-1試験)を採用している。

Fig. 8は各サンプルのQスイッチパルスレーザーに対 するレーザー損傷しきい值を示している。測定したサン プル数は, 機械式研磨14サンプル, プラズマエッチング 処理 11 サンプル, レーザーポリッシュ9サンプルであ る. Fig. 8 より機械式研磨のレーザー損傷しきい值 (平均 值)が $28.4 \mathrm{~J} / \mathrm{cm}^{2}$ であるのに対し，プラズマエッチング処

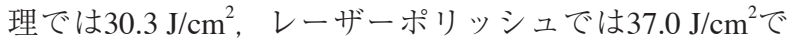
あり, レーザーポリッシュは機械式研磨に比べて, 約 30\%のレーザー損傷しきい值の向上が図られている。な おプラズマエッチング処理とレーザーポリッシュでは, その表面粗さは $0.2 \mathrm{~nm}$ 前後で同等であるが，レーザーポ リッシュはプラズマエッチング処理に比べて $20 \%$ 以上 レーザー損傷しきい值が高い。このことから機械式研磨 で導入されて，完全に除去できなかった研磨傷( スク ラッチ傷)や不純物元素の影響が，プラズマエッチング 処理のサンプルでは未だ存在しているものと考えられ る。また今回得られたレーザーポリッシュでのレーザー 損傷しきい值 $37.0 \mathrm{~J} / \mathrm{cm}^{2}$ は, 後述する石英材料内部の レーザー損傷しきい值 $300 \mathrm{~J} / \mathrm{cm}^{2}$ に比べ, 1 桁程度の差が ある。この原因としては，表面粗さが未だ十分では無い と考えられること, さらに光ファイバ製造工程中にコア 内に形成されると考えられる欠陥の影響があるものと考 えられる。な体稿で取り上げなかった連続発振レー ザーに対するレーザー損傷しきい值の評価に関しては,

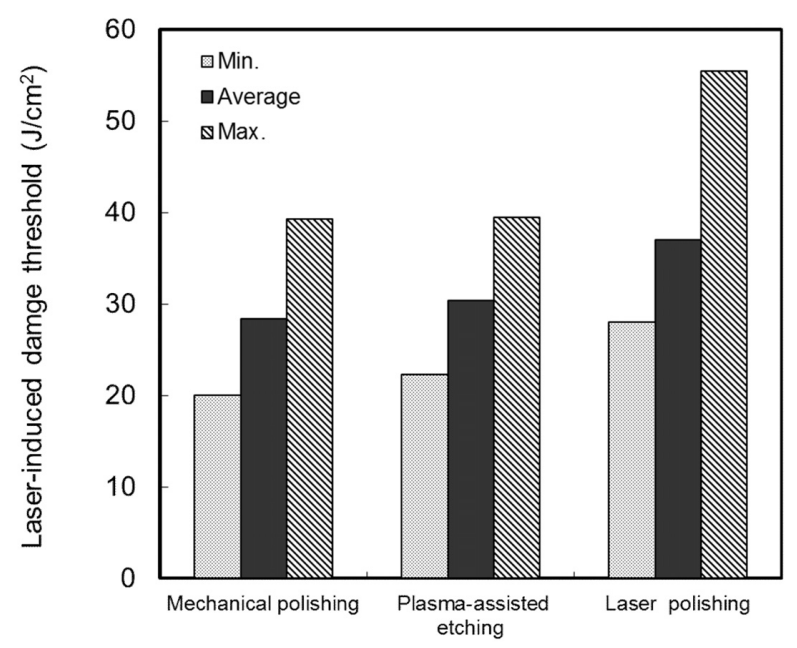

Fig. 8 Laser induced damage threshold of the AR coating on the end face of optical fiber.
その損傷しきい值自身が，光ファイバ端面を取り巻く環 境(光ファイバ自身の構造, コネクタ構造, 冷却雲囲気) の影響を大きく受けるため，具体的な評価方法も含めて 今後の課題と考えられる。

\section{1 .5 エンドキャップ技術}

エンドキャップ技術は，光ファイバ端面に石英コーン (円錐状の石英部材) を融着して，レーザー入射端面での パワー密度を低減させる方法である ${ }^{10)}$ 。一般に石英材料 内部のレーザー損傷しきい值は $300 \mathrm{~J} / \mathrm{cm}^{2}$ と報告されてい るが11)，石英表面は前述の機械式研磨での不純物の侵入 や表面粗さ等の影響により, 内部よりもレーザー損傷し きい值は低い值になると考えられる。そこで石英コーン を融着して, 光ファイバ端面を石英材料内部に埋め込む ことで，表面粗さの課題を解決し，レーザー損傷しきい 值の向上を図っている。 また石英コーンの融着により, レーザー入射端面でのビーム径は拡大され，パワー密度 が低減し，ARコーティングへの負荷も軽減させること が可能である。Fig. 9にコア径600 $\mu \mathrm{m}$ のSIファイバに石 英コーン（直径 $7 \mathrm{~mm}$, 長さ $8 \mathrm{~mm}$ ) を融着した様子を示 す。融着条件の最適化により, 融着部での歪はほとんど 無く，光ファイバへの結合効率の低下は見られない，光 ファイバ端面に石英コーンの融着を行うことで入射面で のビームサイズが拡大され，入射可能なレーザーパワー は，100倍以上に増大することが可能となっている.

\section{2 レーザー伝送用コネクタの耐久性向上技術}

光ファイバのコアに対してレーザー光が正常に入射さ れていない状態，すなわち光ファイバの開口数 $(N A)$ を 越えて入射し続けた場合やコア径よりも大きな集光ス ポット径での入射し続けた場合，あるいは加工対象物か らの強い反射光が光ファイバ端面に戻った場合には，コ ネク夕内部で光ファイバの被覆部が損傷する場合があ る.これらの損傷は, 光ファイバ端面から異常な状態で 入射したレーザー光が，クラッド層内を介して光ファイ バ中を伝搬(いわゆるクラッドモード伝搬)し，その伝搬 途中でレーザーパワーが被覆材料に漏洩し, 吸収されて

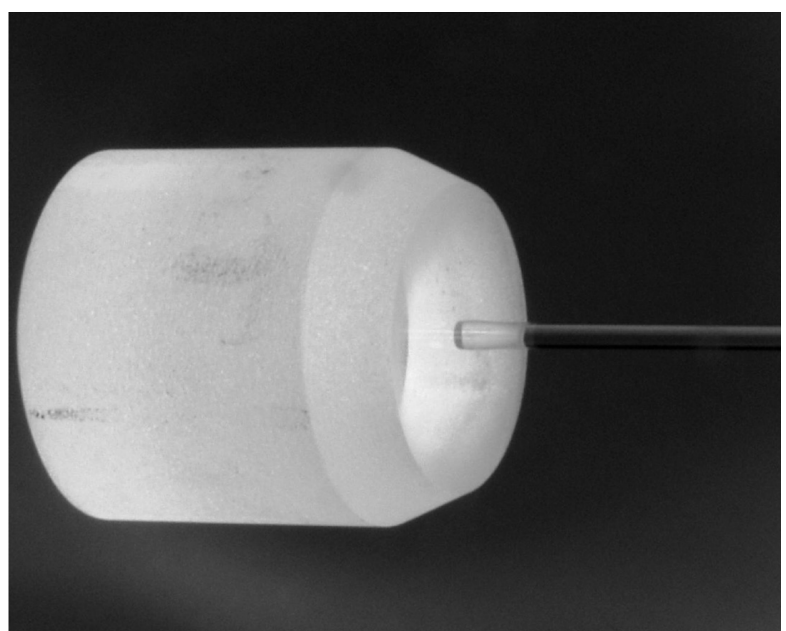

Fig. 9 Photograph of the end cap of laser delivery fiber. 
発熱することが原因となっている

Fig. 10は入射端面を＃1000で粗研磨したコア径400 $\mu \mathrm{m}$ のSIファイバ $(N A 0.4)$ にレーザー光 $(N A 0.3)$ を入射し，入 射端面の散乱により故意に高 $N A$ 成分を発生させ，長時 間レーザー伝送を行った際のコネクタ温度を示してい る。実験では, 入射パワー3.65 Wに対し, 出力パワー $3.15 \mathrm{~W}$ であり，伝搬途中に被覆材料に吸収されるパワー は，入射端面での散乱損失を差し引き， $0.48 \mathrm{~W} ゙$ 差 た. Fig. 10より経過時間200時間後にコネクタ温度が急 上昇して，被覆部の焼損に至っていることが判る．特徴 的な点は焼損直前まで，コネク夕温度や光出力に大きな 変化が現れないことである。またFig. 11は同実験で入射 パワーを調整して, 被覆材料に吸収されるパワーを変化 させ，焼損に至るまでの時間を測定した結果を示してい る。これより焼損に至るまでの時間が，ほぼ吸収パワー で決まることが判る。このような光ファイバの損傷過程 は, 通信用光ファイバに極端な曲げを与えて, 高い入射 パワーを伝搬させた場合にも観察されている ${ }^{12)}$. 急激に 損傷するメカニズムは, 被覆材料がクラッドモード伝搬 光を吸収して劣化が起こると, 材料自身の着色や炭化が

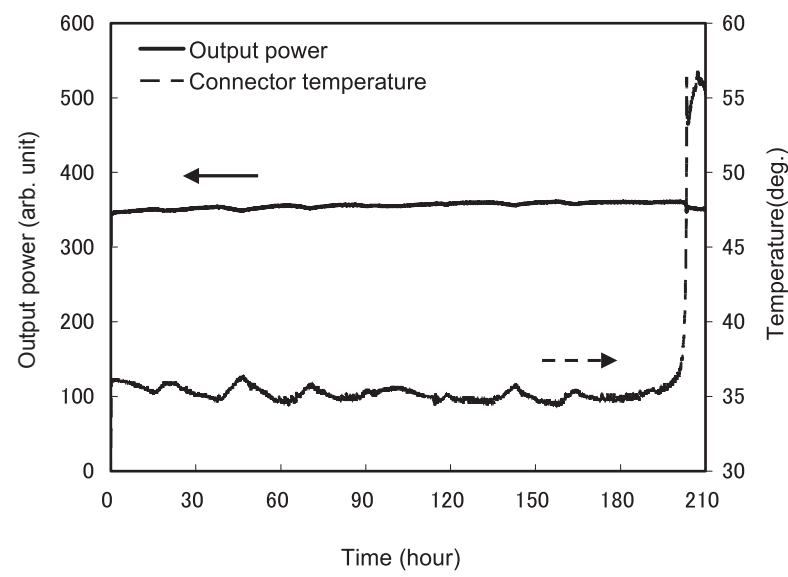

Fig. 10 Connector temperature of the laser delivery fiber under laser incident over $N A$ input.

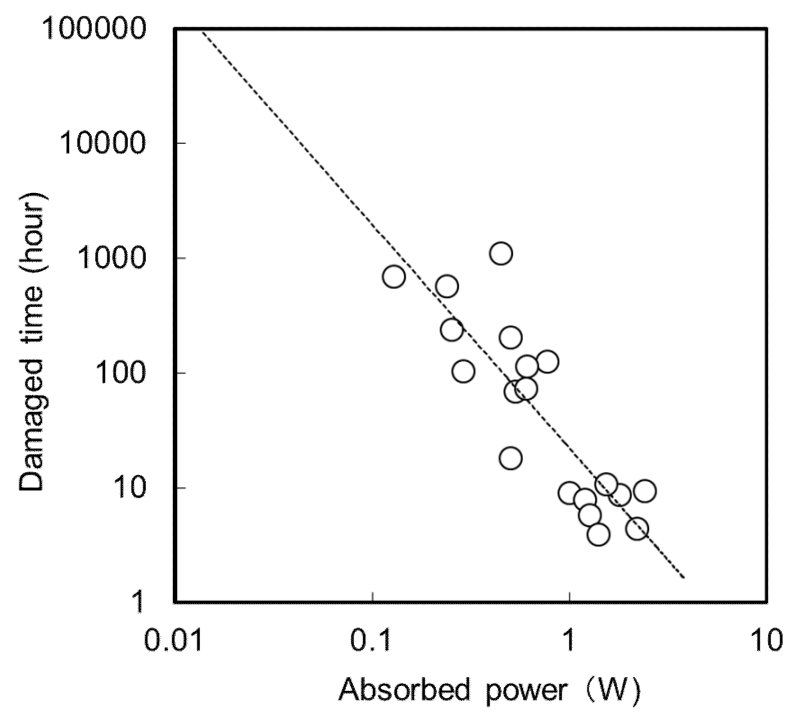

Fig. 11 Relation between damaged time and absorbed power under laser incident over $N A$ input.
進み，更に強い光吸収を起こす。これらが加速度的に繰 り返されて，急激な焼損に至るものと考えられる。なお 損傷に至る過程は，レーザーの入射パワー，高 $N A$ 成分， 周囲の温度環境に大きく影響されると考えられるが，概 して高 $N A$ 成分を含みやすい高出カレーザーの光ファイ バ伝送では, クラッドモード伝搬光に対する対策は重要 と考えられる。

\subsection{1 クラッドモード除去技術}

クラッドモード除去技術は，コネクタ入射端近傍の光 ファイバのクラッド側面に特殊な表面加工により凹凸形 状を形成することで，クラッドモード伝搬光を積極的に 除去する技術である. Fig. 12は光ファイバのクラッド側 面に形成した凹凸形状の一例を示している。図中の右半 分が凹凸形状に加工された部分, 左半分は未加工部分で ある。

光ファイバ側面に形成した凹凸形状のクラッドモード 除去性能について評価を行った。使用した光ファイバ は, コア径 $200 \mu \mathrm{m}, N A 0.20$ のSIファイバであり，光 ファイバ端面から長さ $15 \mathrm{~mm}$ に渡って, 特殊な表面加工 により凹凸形状を形成した。作製したクラッドモード除 去構造付き光ファイバに対して, $\mathrm{HeNe}$ レーザー光(波長 $633 \mathrm{~nm}$ ) を入射 $N A 0.13 \sim 0.40$ の範囲で入射し，各入射 $N A$

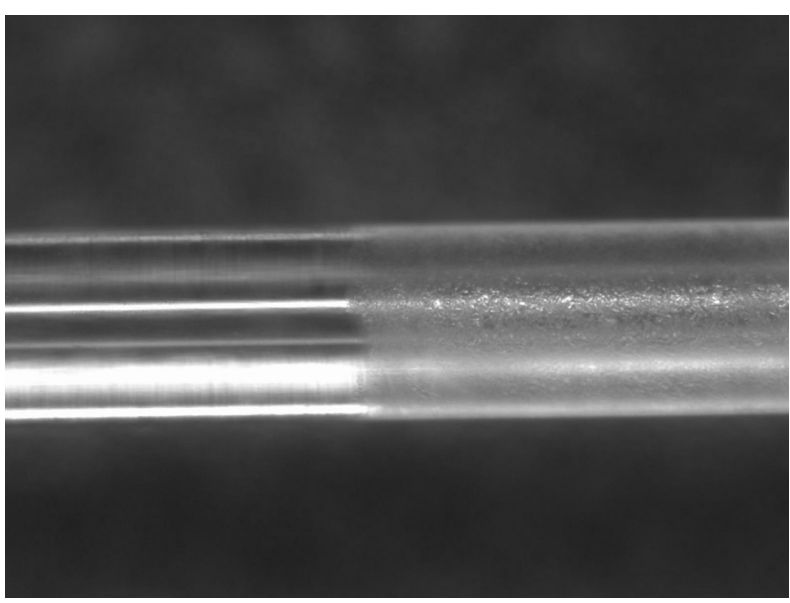

Fig. 12 Unevenness shape of the optical fiber side for removing cladding mode.

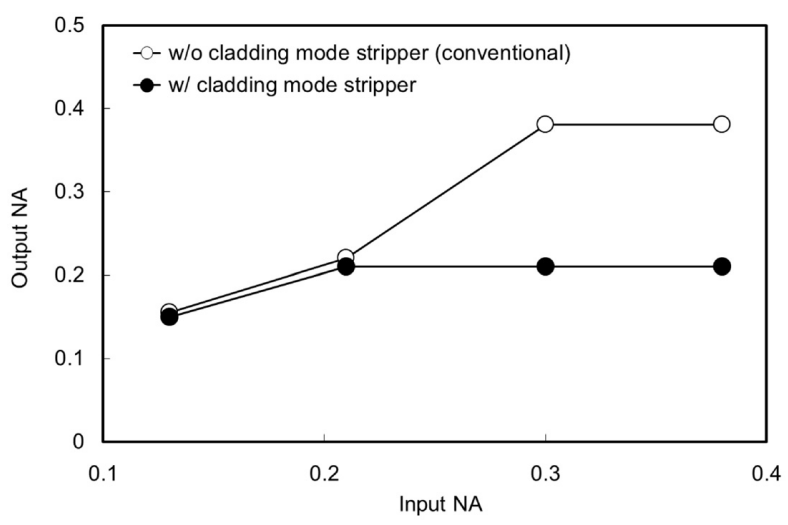

Fig. 13 Relations of $N A$ between input and output in fiber connector with and without cladding mode stripper. 
に対する出射 $N A$ を測定した. Fig. 13に得られた結果を 示す。これよりクラッドモード除去構造が無い場合は, 入射 $N A$ の増加に伴い, 光ファイバのNA0.20以上でも出 射NAは増え続け，クラッドモードが被覆層まで広がっ て伝搬していることが判る。これに対してクラッドモー

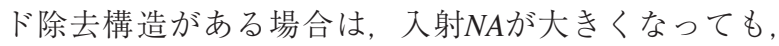
出射 $N A$ 光ファイバのNAである 0.20 に制限され, ク ラッドモード伝搬光が効果的に除去されていることが判 る.このように光ファイバのNAを越えるクラッドモー ド伝搬光に対する除去性能は十分高く, Fig. 10及び Fig. 11に示した被覆部の焼損に対しても高い防止効果が 期待される。 なお実際に本クラッドモード除去技術を適 用する場合は，除去されたクラッドモード伝搬光のエネ ルギーを安全に排出する必要があり，排出するパワーに 応じて冷却構造(水冷方式，空冷方式）を最適に設計する ことで，耐久性の高いレーザー伝送用コネクタが実現さ れる。

\section{4. 結 言}

本稿ではレーザー伝送用光ファイバについて, その信 頼性を支えるための光ファイバ端面加工技術, 及びコネ クタ技術についてその概要を紹介した，今後，レーザー 加工分野では, 更なる加工用レーザー発振器の性能向上
が進み, レーザー伝送用光ファイバの信頼性に対する要 求は益々高まるものと考えられる。 今回紹介した光ファ イバ端面加工技術やコネクタ技術が，高出力レーザー伝 送技術の信頼性を支える技術となることに期待をしてい る。

\section{参考文献}

1) R. Kashyap and K. J. Blow: Electron. Lett. 24 (1988) 47.

2) S. Todoroki: Opt. Express 13 (2005) 6381.

3) Y. Shuto, S. Yanagi, S. Asakawa, M. Kobayashi, and R. Nagase: IEEE J. Lightwave Technol. 21 (2003) 2511.

4）吉田 國男，吉田 英次，本越 伸二：レーザー研究 24 (1995) 11.

5) 實野孝久：NTR News 18 (2002).

6) J. Neauport, L. Lamaignere, and H. Bercegol: Opt. Express 13 (2005) 10163.

7) N. Shibata, S. Shibata, S. Horiguchi, T. Izawa, and H. Osanai: Nat'l Conv.IECE J. 820 (1977) 4.

8) P. A. Temple, W. H. Lowdermilk, and M. David: Laser Induced Damage in Optical Materials 1981, NBS Spec.Pub. 18 (1982) 3249.

9) W. H. Lowdermilk and M. David: IEEE J. Quantum Electron. QE-17 (1981) 1888.

10）山崎元彦, 阿久津剛二, 中村守, 兵藤隆史, 渡部民重, 石田 智彦, 佐竹 武史：三菱電線工業時報 105 (2008) 24.

11) S. Motokoshi, K. Mikami, and K. Kato: Laser-Induced Damage in Optical Materials 2010, Proc. SPIE 7842 (2010) 78420F-1.

12) M. Bigot-Astruc, P. Sillard, S. Gauchard, P. Le Roux, and E. Brandon: Optical Fiber Communication Conference (2006) OFK-4. 